\title{
WRITING THE HISTORY OF THE UNIVERSITY OF TORONTO
}

\author{
Martin Friedland
}

One of my favourite short stories is the one by James Thurber about Jack Pal Smurch, who flew a single-engine second-hand aeroplane around the world without stopping - a feat that had understandably never been done before. When he arrived in New York he gave a press conference on a high floor of one of Manhattan's skyscrapers. "Youse guys," he gloated, "can tell the cock-eyed world dat I put it over on Lindbergh, see?” It was reported in the press the next day that Smurch "accidentally" fell out of an open window - to his death. ${ }^{1}$ I have to be careful not to suffer a similar fate.

The process of selecting me to write the history is succinctly stated in the prologue to the book: "In early June 1997, I received a telephone call from Ron Schoeffel, the editor-in-chief at the University of Toronto Press, asking if I would be interested in submitting a proposal to a university committee charged with deciding who would be invited to write a history of the University of Toronto. The committee, chaired by Father James McConica of the Pontifical Institute of Mediaeval Studies, wanted a scholarly yet accessible one-volume history. The last history of the University had been published in 1927. In the 1970s, material had been collected for a history, but the project was later abandoned. The new history would be published in the year 2002 - the 175th anniversary of the granting of a charter to King's College, the predecessor of the University of Toronto."2

How is it, some have no doubt wondered, that a commerce and finance graduate was asked to write the history of the University of Toronto - and perhaps more importantly, actually wrote the history of the University of Toronto? In order to answer that question I have to be somewhat autobiographical.

\footnotetext{
1 James Thurber, “The Greatest Man in the World,” The Thurber Carnival (New York: Harry \& Brothers, 1945), 154.

2 Martin L. Friedland, The University of Toronto: A History (Toronto: University of Toronto Press, 2002), ix.
}

(C) Historical Studies in Education/Revue d'histoire de l'éducation 14, 2 (2002): 282-298 
It is true that I do not have a background in history. Indeed, I did not even take history in grade 13 . I note, however, that in the epilogue to the history, where I walk through the campus on the last day of the millennium and reminisce about the University, I describe looking up at McMaster Hall on Bloor Street and recalling my favourite undergraduate classes: "the memorable lectures on economic history by Karl Helleiner... and the international relations seminar by Jim Eayrs." ${ }^{3}$ Both courses were, of course, rooted in history.

I went on to law school at $\mathrm{U}$ of $\mathrm{T}$. At that time a course in legal history was not offered. Yet almost all courses were courses in legal history. Bora Laskin's land law course, for example, started with the feudal system. Much of the case law we studied in most courses consisted of early English cases, often going back to the seventeenth century. Lord Mansfield, the chief justice of England in the late eighteenth century, was one of my heroes.

It was not until I went to Cambridge for post-graduate work in 1960 that I did any serious historical digging. My doctoral thesis was on double jeopardy. ${ }^{4}$ It turned out that the historical origins of the concept can be traced back to the conflict between Henry II and Archbishop Thomas à Becket in the twelfth century-and even further back if you include St. Jerome's commentary in 391 A.D. on the prophet Nahum: "For God judges not twice for the same offence." 5 I thought I would have several sentences on the issue, but ended up two months later with eight pages. I still cannot believe how much primary and secondary material exists on a controversy that occurred over eight hundred years ago.

In my criminal law writings over the years I almost always went back to the origins of the concepts and legislative enactments with which I was dealing. One can see this in my studies of the bail system, of gun control, of national security, and of judicial independence, to pick four examples. ${ }^{6}$ Moreover, I had often gone outside libraries to do empirical work to understand how the legal system was in fact working. My first foray in collecting such

3 Ibid., 676.

4 Double Jeopardy (Oxford: Clarendon Press, 1969).

5 Ibid., 5-6, 326-32.

6 Detention Before Trial; A Study of Criminal Cases Tried in the Toronto Magistrates' Courts (Toronto: University of Toronto Press, 1965); "Gun Control: The Options," Criminal Law Quarterly 18 (1975-76): 29ff.; National Security: The Legal Dimensions (Ottawa: Commission of Inquiry Concerning Certain Activities of the Royal Canadian Mounted Police, 1980); A Place Apart: Judicial Independence and Accountability in Canada (Ottawa: Canadian Judicial Council, 1995). 
empirical material had been in the early 1960s when I took 6,000 cases in the Toronto courts over a six-month period to study the workings of the bail system. ${ }^{7}$ I guess one could describe that as "bottom up" legal scholarship, to use the language of historians. ${ }^{8}$ But it was not, however, until 1980 that I actually went into an archive.

I was trying to write a book on law reform and was working on a chapter on codification of the criminal law. I was on sabbatical in Israel in the fall of 1979 and was making progress on the chapter. There were brief references in the literature about a criminal code prepared for Jamaica in the 1870s by a future judge, R.S. Wright, but I could not find anything more about it from the sources that were available to me. I just wanted a footnote. One of the professors from the Hebrew University, ${ }^{9}$ who had worked in the Public Record Office in London, suggested that I might find the answer there. I spent the second half of my sabbatical in Cambridge, England, and went to the Public Record Office in Kew to see what I could find. I never got out of the Kew archives. The footnote grew to a paragraph; the paragraph to several pages; and at the end of the sabbatical I had not completed my chapter on codification of the criminal law but had a long article on R.S. Wright's criminal code for Jamaica-with 324 footnotes. The article-my favourite-entitled "R.S. Wright's Model Criminal Code: A Forgotten Chapter in the History of the Criminal Law"-was accepted for publication in the inaugural volume of the new Oxford Journal of Legal Studies. ${ }^{10}$

The article shaped my future work. In the first place, I discovered how exciting it is to use archival material-the hope that the answer will show up in the next box of material; the absorbing nature of the task, where hours go by quickly; and the challenge of organizing and shaping what has been found. Maybe if I had been trained as an historian I would not have found it so stimulating. I also discovered through that article that a more narrative form could make the material more interesting and comprehensible for the reader. This was a story of a criminal code developed for the colonial office by R.S. Wright that competed with a code prepared by another future judge, James Fitzjames Stephen. Readers of the article, I have been told many times, were

7 Detention Before Trial.

8 E. P. Thompson, “History from Below,” Times Literary Supplement, 6 Apr. 1966, 276.

9 Yoram Schachar.

10 Oxford Journal of Legal Studies 1 (1981): 307ff. 
interested in how the contest would end. What would happen to the two principal code-makers and what would happen to their codes? Colleagues actually read the article from beginning to end.

I learned a great amount about the criminal law through that article. A piece of legislation is the product of conscious choices. It was easy to see this when one contrasted the acceptance of Stephen's conservative criminal code, which Canada adopted in 1892, and Wright's much more liberal code. This is obvious, but I had been teaching criminal law for twenty years and had accepted our criminal code as inevitable, without questioning its origins, and without realizing that a draft tends to reflect the views of the author. The same is true of writing an institutional history and is equally true of the development of the University itself. In both cases there are choices made and alternatives rejected. The University of Toronto we see today was not inevitable. Politics, personalities, and pressure groups have influenced and continue to influence the progress of any institution.

In the course of my work on the Wright article I came across a murder trial over which Justice Stephen presided. A Jewish immigrant from Poland, Israel Lipski, had been charged with murdering a woman in the East End of London in June of 1887. I obtained permission to examine the Home Office records of the case, normally closed for 100 years. In 1984 I published The Trials of Israel Lipski: A True Story of a Victorian Murder in the East End of London. ${ }^{11}$ The book was similar to the R.S. Wright article. It took one specific event or series of events - in this case a trial-and used it as a way of examining the criminal justice system. I stated in the preface of the Lipski book: "This story will place one trial in the context of the social, political and economic conditions of the time. A trial may in theory be an objective pursuit of truth, but in practice there are many subjective factors which influence the course of events. Justice may in theory be blind, but in practice she has altogether too human a perspective."12 In writing the Lipski book, I did not reveal the outcome to reader on the first page, as is usual in academic writing. I did give away at the beginning that Lipski was convicted, but not whether he would be hanged. Indeed, I will not reveal the outcome here. Read the book.

11 London: Macmillan, 1984.

12 Ibid., 11-12. 
I enjoyed writing the Lipski book and wanted to see if I could do a similar book for a Canadian case. I went through the capitalcase files in the National Archives in Ottawa, looking for a Canadian case that would allow me to tell an interesting story and at the same time shed light on the legal system and Canadian society. The Case of Valentine Shortis: A True Story of Crime and Politics in Canada - an analysis of a trial that took place in Quebec in 1895-was published in 1986. ${ }^{13}$

I then turned to an American case. The Death of Old Man Rice: A True Story of Criminal Justice in America followed in 1994. ${ }^{14}$ It examined a turn-of-the century New York case involving a person alleged to have murdered the founder of Rice University. All three murder books increased my knowledge of the nineteenth century, which proved to have been beneficial in tackling the history of the University of Toronto. Moreover, I should add, as a result of working on those books - and reading student exams for forty years-nineteenth-century handwriting never presented a problem for me.

All three murder books are similar. They examine an institution in a scholarly manner, yet try to tell a story that will keep the readers' interest. When I decided to put in a proposal to the committee I said that I would try to do the same in writing the history of the University of Toronto. ${ }^{15}$ I would also try to place the history of the University in the context of the social, political, and economic conditions of the time. As it turned out, many members of the selection committee were familiar with my murder books and probably understood what I would try to do in writing the history of the University. In the fall of 1997 I was informed that I had been selected.

It has turned out to have been the perfect post-retirement project. I worked on the project more-or-less full-time for about four-and-a-half years. I did not teach during that period and had no administrative duties. I was able to keep on top of the material, which might not have been possible if I had had other major responsibilities. I thoroughly enjoyed writing the book.

As I state in the prologue, the history of the University of Toronto is the history of ideas. It is also the history of Toronto, the history of Ontario, and the history of Canada. It is intimately

13 Toronto: University of Toronto Press, 1986.

14 Toronto and New York: University of Toronto Press and New York University Press, 1994.

15 Letter from M.L. Friedland to Ron Schoeffel, July 15, 1997. 
connected with events outside the University. One can, for example, trace over the years the transition from dependence on Great Britain and fear of the United States to the present dominance of American culture and ideas and the decreasing degree of British influence. Life at the University clearly was affected by the two world wars, the cold war, and the Vietnam war. The acceptance within the University of various groups as students and as faculty members also reflects what was happening in society generally. This can be seen, for example, in the 1880s when women were first admitted to University College; or in the expansion of the University in the 1960s because of the baby boomers born after the Second World War; or in the present influx of students caused by the baby-boom echo. ${ }^{16}$ And it can be seen in the mix of races, cultures, and religions in the 1990s because of Canadian immigration patterns in the 1960s and 1970s. And so on.

If one looks at the Old Man Rice book one can see that there is a great similarity in the structure of that book and the $\mathrm{U}$ of $\mathrm{T}$ history. In both I have relatively short chapters or sections. In Old Man Rice the book was divided into 100 sections and seven parts. In my proposal for the U of T history I anticipated that I would have about 80 sections, but in the end that was reduced to about half that number. Coincidentally, the history was also divided into seven parts. The structure of the chapters kept changing, partly to keep the length of the chapters relatively equal, but also because there were natural connections amongst various subjects. Chapter 33 on graduate studies in the 1960s, for example, combines a discussion of Massey College, the Robarts Library, and the School of Graduate Studies in one chapter, rather than in three separate chapters, as I had originally planned. Similarly, as in the murder books, I used relatively short paragraphs and short sentences. There are few semi-colons in the book, although probably a greater number of dashes than in most academic books.

Another similarity is that I personalized the final chapter in each of the murder books, just as I brought myself into the final section of the history. I was uncertain whether the final walk through the campus would work. My impression is that it does, particularly after I changed from calling it chapter 43 to calling it an epilogue and changed the preface to a prologue.

16 David K. Foot with Daniel Stoffman, Boom Bust \& Echo 2000: Profiting from the Demographic Shift in the New Millennium (Toronto: Macfarlane Walter \& Ross, 1998). 
The $\mathrm{U}$ of $\mathrm{T}$ history, like the murder books, makes extensive use of photographs. This enabled me to describe scenes and persons through the photographs. I did not therefore have to use many adjectives or adverbs. Lipski and Shortis had a full-page picture before each chapter. Old Man Rice used 28 pages of pictures - four pages of pictures before each of the seven parts of the book. In the U of T history there are 267 pictures. It took me longer than I expected to collect the pictures. I spent about four months going through all the pictures in the archives and in the $U$ of T development office and other places to select the best pictures. I did not have to describe what Innis or Frye or McLuhan looked like. Their pictures are in the book. Nor did I have to describe the student radicals of the 1960s. There for all to see are Greg Kealey and Andrew Wernick on page 534.

The organization and presentation of the material was a challenge. I wanted to make the history one that people would want to read from the beginning, rather than just concentrate on their own areas of interest. A chronological approach seemed the best way to accomplish this. The faculty of medicine, for example, would be dealt with in a number of places rather than within a single chapter. Similarly, instead of treating broad themes, such as academic freedom, curriculum development, women in the University, and relations with the government, as individual chapters, I would discuss these themes in appropriate places throughout the book.

I was not sure if the chronological approach would be enough to keep the readers' interest and in my proposal I said that I would try to get continuity through the chapters by concentrating on various families with long connections with the University. The Blake family, for example, was one that I planned to use. The family included not only the first professor of law, William Hume Blake, and his son Edward Blake, but also Edward Blake's son-inlaw, historian George Wrong, and Wrong's descendents. Shortly after starting the project, however, I abandoned the idea. It proved to be difficult and somewhat artificial to weave their stories through the history and it did not seem necessary. General themes - such as academic freedom, the position of women, and relations with government-gave continuity to the story, as did the physical development of the University, including discussions of such recurring matters as Taddle Creek.

There also appeared to be a natural continuity in the history through the names of characters that would appear and reappear. I tried to be selective in the number of persons named in the book. 
I had read too many institutional histories over the years that collapsed under the weight of an excessive number of names. Not all vice-presidents and chancellors, and few deans and chairs, make it into the index. I was particularly hard on "distinguished graduates.” A graduate's name was introduced only if it was part of the story of the University. Finance Minister Paul Martin, for example, made it into the index because he said something relevant about the federal government's involvement with research chairs, but his father did not make it into the index. Professors who had not distinguished themselves in a special way or were not an integral part of the overall story of the University tended not to be included.

Each chapter would look at a specific event or time periodoften turning points in the University's history. A chapter would start on a particular date and look backwards at what led up to an issue or event, and then take the story forward in time, usually anticipating the next chapter. Although the whole book is chronological, the individual chapters are not. The first chapter, for example, starts with John Strachan leaving Upper Canada for England in 1826 to get the charter. It does not start with John Graves Simcoe's desire for a university in the 1790s. The chapter ends with Strachan reporting in the fall of 1828 that King's College was "about to open its doors." The second chapter starts with the procession to lay the corner-stone for King's College in 1842. It then looks back at what happened in the intervening fifteen years and then goes forward in time. The chapter ends with Strachan stating that a "godless college" would fail. The next chapter starts with a bill to establish the godless University of Toronto in 1849.

A similar approach is taken in subsequent chapters. Each chapter tries to lead to the next. The structure of the opening and closing of the chapters was always on my mind, just as it had been in the murder books. Each chapter of the history has a specific date attached to it - the date of the first incident being described in the chapter. So, for example, the first chapter is dated 1826, when Strachan left York, and the second chapter is dated 1842, when the cornerstone was laid for King's College. The technique also helps the reader to keep the time period in focus. After completing the book I learned that starting somewhere in the middle of a story is 
a well-known literary device-in medias res, used by Homer in the Iliad and the Odyssey. ${ }^{17}$

The University wanted a one-volume history. I agreed with that decision. My contract with the $\mathrm{U}$ of $\mathrm{T}$ Press called for about 200,000 words of text and the equivalent of about 100 pages of pictures. A one-volume history made sense to me. If one were to go beyond one volume, then why not five volumes or fifteen or, indeed, fifty? Whatever the number of volumes, choices have to be made in what will be included. I also decided to bring the history close to the present - to the year 2000. As I state in the prologue, "I wanted the story to have a happy ending." Moreover, there was not an obvious earlier point to end the history. I knew all the presidents from Sidney Smith on. If I had to end the history at the point where I start to know the participants I would have to end it before World War I, where I mention F.C.A. Jeanneret as a participant in the pre-war COTC. Forty years later, I had extensive dealings with Jeanneret when he was the principal of University College and I was the president of the UC Literary and Athletic Society.

As many of you know, an earlier attempt was made to write the history of the University of Toronto. It was to have been a twovolume history. English professor Robin Harris was appointed University Historian in 1970 and spent the next thirteen years either full-time or part-time on the task. In 1974, professor of history Gerald Craig was appointed to write the history up to the University of Toronto Act of 1906. Harris would cover the period 1906 to 1972 . Each volume was to be separately published under the author's own name. I will leave it to others to study why the project was not successful. Illness clearly played a key role in Craig's inability to complete his part of the project. ${ }^{18}$

Professor Harris deposited his papers in the archives in 1983 and in a background document accompanying the material he described the main problem he faced in writing the history. "The problem I could not solve," he stated, "was the presentation of the material in human terms." ${ }^{19}$ He illustrated the issue by discussing

17 The Encyclopedia Americana: International Edition, 2000 ed., "Odyssey”; "in medias res,” Encyclopaedia Britannica <http:search.eb.com/eb/article?eu=43183>.

18 Kenneth McNaught, "Obituary: Gerald M. Craig,” Ontario History 80, 3 (Sept. 1988): 270; J.M.S. Careless, “Gerald Craig, 1916-1988,” Canadian Historical Society Historical Papers 1988, 300.

19 University of Toronto Archives, A1983-0036, Robin Harris, Finding Aid, "Manuscript Material, Documents and Research Notes for 'A History of the University of Toronto 1906-1958'” (July 1983), vii-viii. 
Kathleen Russell, the director of the nursing program at the University, who had been appointed to the University in 1920. "I contemplated," Harris wrote, “devoting perhaps three pages to Miss Russell, including a lengthy quotation from one of her annual reports as director..." "The trouble is," he went on, "that between 1906 and 1972 the University of Toronto had between 100 and 200 Kathleen Russells. Two of them were Bernhard Fernow, the first dean of the Faculty of Forestry, and William Pakenham, the dean of the Faculty of Education from 1907 to 1920 and of the Ontario College of Education from 1920 to 1934 ...Since, in my opinion, the University of Toronto is the Kathleen Russells - and the Bernhard Fernows, the William Pakenhams, the Harold Innises, the John C. McLennans, the Northrop Fryes - I have decided to call a halt."

It was clear to me that I could not possibly write the history of each division of a university as complex as the University of Toronto. That is for each division to do, as many have done, encouraged by Harris. I discuss Russell, Fernow, and Pakenham in brief individual paragraphs where I set out the origins of their respective divisions. Of course, Innis, McLennan, and Frye-as major university figures-get much more attention.

The material that Harris collected and deposited in the archives was helpful to me. He had a great number of talented research assistants whose work made my task much easier than it otherwise would have been. I also had the advantage of extensive secondary literature that had been published about the University of Toronto over the past thirty years. Brian McKillop's magisterial book, Matters of Mind: The University in Ontario, 1791-1951, ${ }^{20}$ was particularly helpful, giving me an overview that allowed me to select at an early stage some of the key areas to explore. There were also several excellent books on University of Toronto presidents: Elizabeth Hulse's book on Daniel Wilson, James Greenlee's on Robert Falconer, and D.C. Master's on Henry Cody. ${ }^{21}$ Plus, there were fine autobiographical writings, such as

20 Brian McKillop, Matters of Mind: The University in Ontario, 1791-1951 (Toronto: University of Toronto Press, 1994).

21 Elizabeth Hulse, ed., Thinking with Both Hands: Sir Daniel Wilson in the Old World and the New (Toronto: University of Toronto Press, 1999); James Greenlee, Sir Robert Falconer: A Biography (Toronto: University of Toronto Press, 1988); D.C. Masters, Henry John Cody: An Outstanding Life (Toronto: Dundurn Press, 1995). 
those by Claude Bissell, Ernest Sirluck, and Robert Blackburn. ${ }^{22}$ Moreover, I had at least a dozen doctoral theses relating to the University of Toronto. Those presenting papers today are responsible for more than another dozen books and countless articles containing extensive discussions about aspects of the University of Toronto.

In addition, I had the benefit of computers and the internet. The use of e-mail allowed me to collect information easily. As we all know, people are more willing to respond by e-mail than by sending a letter. E-mail also allowed me to communicate easily with my research assistants, individually and collectively. Drafts were constantly being sent back and forth by attachments. It was not necessary to be in my office in the archives to keep in close touch with my research assistants. Moreover, having the drafts on the internet was one more form of back-up. I also had the drafts on my home computer, my office computer at the law school, and two computers in the archives, as well as on floppies. As it turned out, we never lost any material and so I did not need such elaborate back-ups. But it allowed me to sleep better, which indirectly contributed to the completion of the project. One other advantage of the computer was that it was easy to do word counts that helped me to keep the length of chapters under control. Further, I always kept the date and the word count at the top of each draft of a chapter. This enabled us to keep track of the great quantity of material we were producing. Some of the chapters went through more than ten drafts.

The internet had another great advantage. The notes could be placed on a website on the internet, which meant that the manuscript could have detailed notes without sacrificing space in the book itself. There are about 10,000 notes. We were, however, able to include in the book thirteen pages on the sources used for each chapter, and eighteen pages for a bibliography limited to those sources. The U of T Press developed and maintains the website. ${ }^{23}$ I worked closely with the Press for months trying to get the most user-friendly format. We use Adobe's PDF format. You can click on individual chapters or the entire text. Another advantage of

22 Claude Bissell, Halfway up Parnassus: A Personal Account of the University of Toronto, 1932-1971 (Toronto: University of Toronto Press, 1974); Ernest Sirluck, First Generation: An Autobiography (Toronto: University of Toronto Press, 1996); and Robert $\mathrm{H}$. Blackburn, Evolution of the Heart: A History of the University of Toronto Library up to 1981 (Toronto: University of Toronto Press, 1989).

23 www.utppublishing.com and follow the links. 
using the internet is that one can do an electronic search of the footnotes. The notes are also available in a hard-copy edition, with its own ISBN number for cataloguing purposes. ${ }^{24}$ I know all the presenters today were offered copies of the notes and no doubt have also used the website. I will be interested in your reactions.

Still another advantage is that the notes can be changed. The notes are now current as of publication date, March 15, 2002, and will be updated from time to time to correct errors. Future changes will be clearly indicated in the notes, perhaps by using square brackets. The current version of the notes includes some material that would have gone into the text if it had been discovered in time. One such matter was a discovery that Charles Levi made, a few months before publication, of a memo from the registrar, Robin Ross, to Claude Bissell in 1959 making it clear that the faculty of medicine discriminated against Jews as late as $1959 .{ }^{25}$ Up until finding that note I felt I could not go further in the text than stating that "it appears reasonably clear from both the anecdotal and the statistical evidence available that discriminatory practices prevailed for a period of time” after a discretionary admission policy was introduced in $1942 .^{26}$

This is the first time that the $\mathrm{U}$ of $\mathrm{T}$ Press put all of the footnotes on the internet. Connie Backhouse's book, ColourCoded ${ }^{27}$ had used the internet for additional material for individual footnotes that could not be included in the book itself because of space concerns. Other publishers have been putting material on the internet as well. Some have placed bibliographies and some have placed the whole book, including footnotes, on the web. ${ }^{28}$ One

24 Martin L. Friedland, Notes: The University of Toronto: A History (Toronto: University of Toronto Press, 2002), ISBN 0-8020-8526-1.

25 Editors' note: For Charles Levi's essay on this discovery, see the next issue of Historical Studies in Education, spring 2003.

26 The University of Toronto: A History, 352.

27 Connie Backhouse, Colour-Coded: A Legal History of Racism in Canada (Toronto: University of Toronto Press, 1999).

28 See Robert Kaplan, The Nothing That Is: A Natural History of Zero (Oxford: Oxford University Press, 2000); Robin Marantz Henig, The Monk in the Garden: The Lost and Found Genius of Gregor Mendel, the Father of Genetics (Boston: Mariner Books, 2001); Michael A. Bellesiles, Arming America: The Origins of a National Gun Culture (New York: Alfred A. Knopf, 2000); John Crewdson, Science Fictions: A Scientific Mystery, a Massive Coverup and the Dark Legacy of Robert Gallo (New York: Little, Brown, 2002); and Michael Jackson, Justice Behind the Walls (Vancouver: Douglas \& McIntyre, 2002). See also the review of Science Fictions in the New York Times, April 12, 2002, and Derek Weiler, "Canadian projects put scholarly research on the Web," Quill \& Quire, Nov. 1999, 38. For a comprehensive discussion of the issues surrounding the use of the internet for scholarly work, see John Court, "Bibliographies and Notes as a Separate 
problem was how to place the notes on the web, but not include footnote numbers in the text. Ron Schoeffel, the then-editor-inchief of the Press, suggested that we adopt the technique that he had been using for some of the volumes in the Press' Erasmus series, where they have translations of Erasmus' writings, without footnote numbers embedded in the text. The text is identified by page and line number and the particular passage being commented upon. In the history, we decided to use page, paragraph, and phrase or word.

My research assistants were uniformly excellent. I was helped in the formulation of the proposal in the summer of 1997 by my two summer research assistants, who had just finished first-year law school: Graham Rawlinson, who had left history for the law and is now with the law firm Torys, and Katrina Wyman, who has just taken a tenure-stream position at NYU law school. After the project got underway, Charles Levi, who had just submitted his doctorate in history at York University under Paul Axelrod, became my principal research assistant. Charles was a fabulous researcher. If there was a document that needed to be found, Charles would find it. Michiel Horn described Charles in the acknowledgements to his book on academic freedom as "incomparable." 29 I agree.

I had intended to allocate my funds for research more or less equally over the life of the project. I had so many excellent applications to work on the project for the first summer that I changed course and hired six persons in addition to Charles to help me collect material. I won't name them all, but will note two of the researchers: Sara Burke, who is presenting a paper today, helped me collect material on women in the University, and Michael McCulloch, who has his doctorate in nineteenth-century Canadian history and had just finished first-year law, assisted me in understanding the history of the early years of the University. ${ }^{30}$

We were also helped immensely by the staff of the $\mathrm{U}$ of $\mathrm{T}$ Archives, and particularly by Harold Averill. There is not a scholar in this room who has worked on aspects of U of T's history who

Online Publication: A Novel Trend in Support of Historical Publishing,” paper presented at "Research in Progress-Seminar 2002," Toronto, May 22, 2002, sponsored by the Centre for Addiction and Mental Health and the Canadian Society for the History of Medicine's Website Collaborative.

29 Michiel Horn, Academic Freedom in Canada: A History (Toronto: University of Toronto Press, 1999), xiv.

30 David Bronskill, Sara Burke, Colin Grey, Kelly de Luca, Michael McCulloch, Tim Meadowcroft, Patrick Okens, and Sam Robinson. Subsequently, Suzanne Dicerni assisted with a number of tasks. 
would not acknowledge how important Harold has been to his or her own project. Harold and others within and outside the University were generous with the time they spent commenting on drafts of chapters or on the entire manuscript. Bob Gidney and Wyn Millar, to give two heroic examples, read two versions of the manuscript and their perceptive comments were valuable in helping shape the final product.

Let me say something about how I went about the research. Many of the methods I used for this project were similar to those I used for my $\mathrm{PhD}$ thesis forty years earlier-even though there were then no personal computers, nor were there photocopiers, nor even sticky tabs. I suspect that the research techniques for one's doctorate stick with you for life. I still use a small Bambi stapler that I used for my thesis. I get a fresh supply of staples whenever I am in England. I ran out during the project and had a friend in England send me a new batch. And I wonder how closely one's research techniques match the research techniques of one's supervisor, just as I suspect one's writing style tries to mirror that of one's supervisor, as mine did. My supervisor was Glanville Williams of Cambridge, whose writing style I admired. When I first met with him I confessed to him that I had done very little writing as an undergraduate or at law school and was very unsure of that aspect of producing a thesis. To my surprise, he said that he had had the same fear when he started his thesis and decided to study the style of historian E.H Carr. I decided to study Glanville Williams' style. Whether my style still reflects his style, or, indirectly, E.H. Carr's, I am uncertain. In general, I try to follow the advice I recently saw on a bumper sticker: "eschew obfuscation."

For what it is worth, here is the way I went about the writing of the history. It may help persons who have not yet had to deal with masses of research material. I used standard spiral binders to make notes of the material I was reading, just as I had in Cambridge. For my thesis the binders had to be cut up and distributed to appropriate file folders. For later projects, including the present book, I would make photocopies of the pages and distribute them to the files, so that I would have both the spiral binders and the material in the files. I never used cards, as I see many persons still do. With the spiral binders I never have to worry about mixing up the cards. I do not have advice on how to organize the files except to say that I have found in every project that I have done that I am constantly reorganizing the subject matter and the 
contents of the files. The accumulation of material inevitably causes one to reassess its organization.

As with my thesis, I embedded the references in whatever text I was writing so that I would not have to search for the references later. The text with the embedded references would be sent by email to one of my research assistants, usually Charles, who would change the embedded references into proper footnotes. Because of the extent of the material we had to keep track of and the need to find the material quickly, Charles and I developed a system whereby there was a large three-ringed binder for each chapter, containing photocopies of the precise pages we had cited, with the relevant parts circled. The material was put in the binder according to the source, such as the U of T Bulletin or a particular book or article. There are tables of contents for each binder which allowed us to find material easily. We rarely had to spend time tracking down a lost document. All of the forty or so binders are being deposited in the archives along with other material on the project.

The use of our own photocopier in our own room in the archives was crucial for the project. Indeed, in the negotiations leading to the contract it was one of the few conditions I insisted upon. We could photocopy material when we needed it and, if necessary, it could be faxed to me at home, where I did the writing, from our office in the archives.

Since completing the history I have read some of the literature on writing history. ${ }^{31}$ It was probably an advantage not to have read it before the book was finished. I could naively continue to do what I had been doing before. As I read the material, I kept wondering how the $\mathrm{U}$ of $\mathrm{T}$ history fit into the various theories. What would the speakers at this conference say? The manuscript certainly fits into a narrative style. ${ }^{32}$ It attempts to place the history in the context of the times by looking at relevant social, political, and economic conditions. Is it top down or bottom up? ${ }^{33}$ I guess

31 See, for example, Peter Burke, ed., New Perspectives on Historical Writing, $2^{\text {nd }}$ ed. (University Park: Pennsylvania State University Press, 2001); Carl Berger, The Writing of Canadian History: Aspects of English-Canadian Historical Writing: 1900-1970 (Toronto: Oxford University Press, 1976); Berger, Contemporary Approaches to Canadian History (Toronto: Copp Clark Pitman, 1987); E. H. Carr, What is History?, $2^{\text {nd }}$ ed. (London: Macmillan, 1986); and Joyce Appleby, L. Hunt, and M. Jacob, Telling the Truth about History (New York: Norton, 1994).

32 Lawrence Stone, “The Revival of Narrative,” Past and Present, 85 (1979): 3; Natalie Zemon Davis, The Return of Martin Guerre (Cambridge, Mass.: Harvard University Press, 1983).

33 Thompson, “History from Below,” 276. 
it is both, but mainly top down. It is hard for an institutional history to avoid discussing presidents and other senior administrators. But I did not divide the chapters according to presidents. The selection of a new president was usually dealt with in the middle of a chapter.

I tried to include detailed descriptions of events from the students' perspectives, such as the chapter on the admission of women and the student strike of 1895. It is not, however, a history of students or of women. Charles Levi and Sara Burke, respectively, can still write their own books on those subjects without worry that the field has been covered.

In some places I go into great detail to describe an event. Some of these may be the $U$ of $T$ equivalents of the Balinese cockfights described by Clifford Geertz. ${ }^{34}$ In addition to the fight over the admission of women and the student strike, there is the detailed discussion of the contest over whether Cody or Massey would be the chancellor, and the struggle between the administration and the faculty association over the memorandum of agreement.

Finally, let me say something about the difference between a lawyer's interpretation of evidence and an historian's approach. In my view, there should not be a difference. Lawyers and judges tend to draw inferences from the evidence the same as historians. The same considerations of memory, potential bias, and other factors should influence historians and lawyers equally. There are differences, however, concerning the admissibility of evidence. For policy reasons, certain relevant evidence is excluded from the trier of fact as a matter of law. Solicitor-client privilege, which is necessary in order to permit persons to communicate freely with their lawyers, is one example. The exclusion of character evidence, which is designed to protect the accused from a jury saying, "we don't care whether he is guilty or innocent, he should be behind bars," is another. And, of course, historically, hearsay evidence tended to be excluded, although the hearsay rules have been changing in recent years. The law also differs from the historian's approach by setting out standards of proof, such as proof beyond a reasonable doubt in a criminal case and proof on a balance of probabilities in a civil case. But on the basic question of whether an inference should be drawn from the evidence available, I do not see that there is or should be any difference.

34 Clifford Geertz, The Interpretation of Cultures: Selected Essays (New York: Basic Books, 1973). 
I'll stop there. I was asked to talk about the writing of the history of the University of Toronto. I have done that, although I may have said more than you want to know about how the history was written. 